\title{
Hubungan Pengetahuan dan Dukungan Keluarga dengan Kepatuhan Minum Obat Anti Tuberkulosis di Puskesmas Andalas Kota Padang
}

Ivan Putra Siswanto ${ }^{1}$, Yanwirasti², Elly Usman ${ }^{3}$

\begin{abstract}
Abstrak
Tuberkulosis merupakan masalah kesehatan dunia terutama di negara yang dikelompokkan dalam high burden countries termasuk Indonesia. Pada tahun 2012, Indonesia berada di posisi empat dengan jumlah penderita TB terbanyak di dunia. Berdasarkan laporan tahunan Dinas Kesehatan Kota Padang tahun 2010, kesembuhan di Puskesmas Andalas sebesar 75,9\%. Angka ini masih dibawah target pencapaian nasional sebesar $85 \%$. Pada tahun 2011, angka kesembuhan di Puskesmas Andalas naik cukup signifikan yaitu mencapai 88,24\% yang melebihi target nasional. Tujuan penelitian ini adalah menentukan hubungan antara pengetahuan pasien TB paru dan dukungan keluarga terhadap kepatuhan minum obat anti-tuberkulosis di puskesmas Andalas Kota Padang. Desain penelitian yang digunakan cross sectional study dengan jumlah subjek sebanyak 26 orang penderita TB paru yang melakukan pengobatan di Puskesmas Andalas. Data dikumpulkan melalui wawancara kepada responden menggunakan kuisioner yang kemudian di analisis melalui uji chi-square dengan derajat kepercayaan 95\%. Pada penelitian didapatkan hubungan antara pengetahuan pasien TB paru $(p=0,000)$ dan dukungan keluarga $(p=0,04)$ dengan kepatuhan minum obat anti-tuberkulosis di Puskesmas Andalas Kota Padang.
\end{abstract}

Kata kunci: tuberkulosis paru, kepatuhan, pengetahuan, dukungan keluarga

\section{Abstract}

Tuberculosis is a global health problem, especially in countries that are grouped in high-burden countries, including Indonesia. In 2012, Indonesia was in fourth position with the highest number of TB patients in the world. Based on the annual report of Padang City Health Department in 2010, succeed rate in Andalas Health Centre in Padang was $75.9 \%$ and this was below natonal target (85\%). In 2011, succeed rate in Andalas Health Centre in Padang increased significantly, 88.24\% which exceed national target. The objective of this study was to determine the relationship between knowledge of pulmonary TB patients and family support to adherence of anti-tuberculosis drugs at the health center patients Andalas Padang. The design of this study was cross sectional study. There were 26 subjects of pulmonary TB patient on treatment in Andalas Health Centre which were taken by total sampling. Data were collected through interview using questionnaire and analyzed by chi square test with 95\% confidence interval. The results showed an association between patients knowledge ( $p$-value: 0.000) and family support ( $p$-value: 0.04) with medication adherence in Andalas Health Center, Padang City.

Keywords: pulmonary tuberculosis, adherence, knowledge, family support

Affiliasi penulis: 1. Pendidikan Dokter FK UNAND (Fakultas Kedokteran Universitas Andalas Padang), 2. Bagian Anatomi FK UNAND, 3. Bagian Farmakologi FK UNAND.

Korespondensi: Ivan Putra Siswanto,

E-mail: ivanputra.s@gmail.com, Telp: 085263599583

\section{PENDAHULUAN}

Tuberkulosis (TB) masih menjadi masalah kesehatan di dunia maupun di Indonesia. Diperkirakan sepertiga penduduk dunia telah terinfeksi oleh kuman Mycobacterium tuberculosis. Penyakit TB paru banyak 
menyerang kelompok usia kerja produktif dari kelompok dengan sosial ekonomi dan pendidikan rendah. $^{1}$

Kekebalan ganda (multidrug resistance $=M D R$ ) terhadap obat anti TB semakin menjadi masalah akibat kasus yang tidak berhasil disembuhkan. Keadaan tersebut pada akhirnya akan menyebabkan terjadinya epidemi TB yang sulit ditangani. ${ }^{2}$ MDR merupakan masalah terbesar terhadap pencegahan, pemberantasan TB, dan merupakan hambatan terhadap efektivitas program penanggulangan TB di dunia dan di Indonesia. 3,4

Indonesia termasuk dalam high burden countries bersama 21 negara lainnya. Estimasi prevalensi semua kasus TB yang terjadi Indonesia diperkirakan sebesar 660.000 dan estimasi insidensi kasus baru sebesar 430.000 tiap tahun. Korban meninggal akibat TB di Indonesia diperkirakan sebanyak 61.000 kematian tiap tahunnya. ${ }^{5}$ Berdasarkan laporan World Health Organization (WHO) tahun 2012, Indonesia berada di posisi empat dengan jumlah penderita sekitar 0,4 juta $-0,5$ juta di bawah India, China, dan Afrika Selatan. ${ }^{6}$ Salah satu indikator pengendalian TB adalah Case Detection Rate (CDR), yaitu penemuan kasus baru TB BTA positif paling sedikit $70 \%$ dari perkiraan dan Success Rate (SR) angka keberhasilan pengobatan paling sedikit $85 \%$ dari semua pasien tersebut serta mempertahankannya. ${ }^{2}$

Sumatera Barat termasuk kedalam provinsi yang belum mencapai target penanggulangan TB nasional. Pada tahun 2006, angka CDR Sumatera Barat sebesar $50,1 \%$ dan mengalami penurunan tahun 2007 menjadi 48,35\%. Pada tahun 2010 angka CDR di kota Padang adalah 853 kasus (62\%) dari 1.376 BTA positif yang diperkirakan, naik dibanding tahun 2009 yaitu 748 kasus (56,5\%) dan tahun 2008 sebanyak 699 kasus (52\%). Angka SR kota Padang pada tahun 2010 sebesar $71,4 \%$, naik dibandingkan angka kesembuhan untuk penderita baru TB paru Basil Tahan Asam (BTA) positif pada tahun 2008 yaitu sebanyak 349 penderita $(62,8 \%) .^{7,8}$
Pada tahun 2010, angka kesembuhan di Puskesmas Andalas sebesar 75,9\%. Angka ini masih dibawah target pencapaian nasional yaitu sebesar 85\%. Pada tahun 2011, angka kesembuhan di Puskesmas Andalas naik cukup signifikan yaitu mencapai $88,24 \%$ yang melebihi target nasional. ${ }^{7}$

Kepatuhan pasien dalam minum obat merupakan faktor penting dalam keberhasilan suatu pengobatan. Pengobatan TB paru yang lama sering membuat pasien bosan dan menimbulkan ketidakpatuhan pasien dalam minum obat. Permasalahan kepatuhan pasien penyakit TB paru di pengaruhi banyak faktor, yaitu faktor obat, faktor sistem kesehatan, faktor lingkungan, faktor sosial ekonomi, dan faktor pasien. Dukungan keluarga dan pengetahuan pasien terhadap penyakit tuberkulosis, obat anti tuberkulosis, dan keyakinan terhadap efikasi obatnya akan mempengaruhi keputusan pasien untuk menyelesaikan terapinya atau tidak. ${ }^{9,10}$

Tujuan penelitian ini adalah untuk menentukan hubungan antara pengetahuan pasien TB paru dan dukungan keluarga terhadap kepatuhan minum obat anti tuberkulosis di Puskesmas Andalas Kota Padang.

\section{METODE}

Penelitian ini dilakukan di wilayah kerja Puskesmas Andalas Kota Padang dari Agustus 2012 sampai Mei 2013. Subjek adalah pasien TB Paru baru dengan BTA positif dengan kategori I, mengikuti pengobatan di Puskesmas Andalas dan bersedia ikut dalam penelitian. Pengambilan subjek menggunakan teknik total sampling. Data diperoleh dengan wawancara langsung kepada penderita TB paru yang berpedoman pada kuesioner yang telah ditetapkan.

\section{HASIL}

Berdasarkan penelitian yang telah dilakukan didapatkan subjek yang memenuhi kriteria sebanyak 26 pasien.

Pada Tabel 1 dapat dilihat bahwa persentase tertinggi pada jenis kelamin laki-laki dengan usia 16-25 tahun dan tingkat pendidikan terakhir adalah SMA. 
Tabel 1. Data karakteristik penderita TB paru

\begin{tabular}{|c|c|c|c|}
\hline No & Karakteristik & $f$ & $\%$ \\
\hline \multirow[t]{7}{*}{1} & Umur & & \\
\hline & $16-25$ & 9 & 34,6 \\
\hline & $26-35$ & 4 & 15,4 \\
\hline & $36-45$ & 1 & 3,8 \\
\hline & $46-55$ & 5 & 19,2 \\
\hline & $56-65$ & 3 & 11,5 \\
\hline & $66-75$ & 4 & 15,4 \\
\hline \multirow[t]{3}{*}{2} & Jenis Kelamin & & \\
\hline & Laki-laki & 18 & 69,2 \\
\hline & Perempuan & 8 & 30,8 \\
\hline \multirow[t]{5}{*}{3} & Tingkat Pendidikan Terakhir & & \\
\hline & SD & 7 & 26,9 \\
\hline & SMP & 8 & 30,8 \\
\hline & SMA & 10 & 38,5 \\
\hline & Sarjana & 1 & 3,8 \\
\hline
\end{tabular}

Tabel 2 dapat diketahui bahwa 69,2\% responden di Puskesmas Andalas Kota Padang patuh dalam minum obat.

Tabel 2. Frekuensi dan distribusi kepatuhan minum obat responden

\begin{tabular}{ccc}
\hline Kepatuhan & $\mathbf{f}$ & $\%$ \\
\hline Patuh & 18 & 69,2 \\
Tidak Patuh & 8 & 30,8 \\
\hline Jumlah & 26 & 100,0 \\
\hline
\end{tabular}

Dari Tabel 3 diketahui responden di Puskesmas Andalas Kota Padang memiliki pengetahuan yang baik terhadap TB paru dan mendapatkan dukungan dari keluarga responden.

Tabel 3. Frekuensi dan distribusi variabel independen

\begin{tabular}{clcc}
\hline No & Variabel Independen & f & $\%$ \\
\hline 1 & Pengetahuan Responden & & \\
& Baik & 18 & 69,2 \\
& Tidak Baik & 8 & 30,8 \\
\multirow{2}{*}{ Dukungan Keluarga } & & \\
& Ada & 20 & 76,9 \\
& Tidak Ada & 6 & 23,1 \\
\hline
\end{tabular}

Tabel 4 memperlihatkan responden yang patuh minum obat lebih banyak ditemukan pada responden yang memiliki pengetahuan baik $(94,4 \%)$ dibandingkan responden yang memiliki pengetahuan tidak baik $(12,5 \%)$. Dengan uji statistik terdapat perbedan yang bermakna kepatuhan minum obat berdasarkan baik atau tidak pengetahuan responden $(p=0,000)$.

Tabel 4. Hubungan pengetahuan tentang TB Paru dengan kepatuhan minum obat

\begin{tabular}{lccccccc}
\hline \multirow{2}{*}{$\begin{array}{c}\text { Pengetahu } \\
\text { an }\end{array}$} & \multicolumn{9}{c}{ Kepatuhan } & \multicolumn{1}{c}{ Patuh } & \multicolumn{2}{c}{ Tidak } \\
\cline { 2 - 6 } & Patuh & Jumlah & & P \\
\cline { 2 - 6 } & $\mathbf{f}$ & $\%$ & $\mathbf{f}$ & $\%$ & $\mathbf{f}$ & $\%$ & \\
\hline Baik & 17 & 94.4 & 1 & 5,6 & 18 & 100 & 0,00 \\
Tidak Baik & 1 & 12,5 & 7 & 87,5 & 8 & 100 & 0 \\
\hline Jumlah & 18 & 69,2 & 8 & 30,8 & 26 & 100 & \\
\hline
\end{tabular}

Pada Tabel 5 dapat dilihat bahwa 17 responden yang patuh minum obat mendapatkan dukungan keluarga sedangkan hanya 1 responden yang tidak mendapatkan dukungan keluarga. Ada perbedaan yang bermakna kepatuhan minum obat berdasarkan ada atau tidak adanya dukungan keluarga $(p=0,04)$.

Tabel 5. Hubungan dukungan keluarga tentang TB paru dengan kepatuhan minum obat

\begin{tabular}{|c|c|c|c|c|c|c|c|}
\hline \multirow{3}{*}{$\begin{array}{c}\text { Dukungan } \\
\text { Keluarga }\end{array}$} & \multicolumn{4}{|c|}{ Kepatuhan } & \multirow{2}{*}{\multicolumn{2}{|c|}{ Jumlah }} & \\
\hline & \multicolumn{2}{|c|}{ Patuh } & \multicolumn{2}{|c|}{$\begin{array}{l}\text { Tidak } \\
\text { Patuh }\end{array}$} & & & p \\
\hline & $f$ & $\%$ & $f$ & $\%$ & $f$ & $\%$ & \\
\hline Ada & 17 & 85 & 3 & 15 & 20 & 100,0 & 0,0 \\
\hline Tidak Ada & 1 & 16,7 & 5 & 83,3 & 6 & 100,0 & 4 \\
\hline Jumlah & 18 & 69,2 & 8 & 30,8 & 26 & 100,0 & \\
\hline
\end{tabular}

\section{PEMBAHASAN}

Berdasarkan hasil penelitian, diketahui bahwa persentase usia penderita tertinggi di kelompok usia 16-25 tahun yaitu sebesar $34,6 \%$ dan $69,2 \%$ responden berjenis kelamin laki-laki. Penelitian yang dilakukan oleh Fitriani menyatakan adanya hubungan antara usia penderita dengan kejadian Tuberkulosis. ${ }^{11}$ 
Depkes $\mathrm{RI}$ juga menyatakan bahwa $75 \%$ pasien TB. ${ }^{5}$

Pada penelitian yang dilakukan oleh Wahyuni mendapatkan $71,9 \%$ responden berjenis kelamin laki. ${ }^{12}$

Penyakit TB paru BTA positif lebih banyak menyerang kelompok usia produktif disebabkan karena tingginya aktivitas, mobilitas, gaya hidup dan kebiasaan merokok. Aktivitas dan mobilitas yang tinggi akan memberikan kemungkinan yang lebih besar untuk kontak dengan orang lain, sehingga besar pula kemungkinan untuk tertular TB paru. Laki-laki memiliki mobilitas yang lebih tinggi dibandingkan perempuan serta kebiasaan laki-laki yang cenderung mengkonsumsi alkohol dan keluar malam hari yang dapat menurunkan sistem kekebalan tubuh. ${ }^{12}$

TB paru lebih banyak terjadi pada laki-laki dibandingkan wanita karena laki-laki sebagian besar mempunyai kebiasaan merokok. Kebiasaan merokok meningkatkan risiko untuk terkena TB paru sebanyak 2,2 kali. $^{13}$

Berdasarkan hasil penelitian, diketahui bahwa 69,2\% penderita TB paru di Puskesmas Andalas Kota Padang patuh dalam meminum obat yaitu sebanyak 18 responden. Kepatuhan penderita yang diukur mencakup kepatuhan meminum obat dengan cara yang benar, jumlah obat yang diminum sesuai petunjuk petugas kesehatan, pernah terlambat minum obat, dan pernah lupa minum obat. Dari data yang didapatkan dapat dilihat bahwa semua responden $100 \%$ meminum obat sesuai dengan jumlah yang disarankan oleh petugas kesehatan. Sebagian besar responden yaitu $88,46 \%$ meminum obat dengan cara yang benar sesuai dengan petunjuk petugas kesehatan. Responden yang pernah terlambat minum obat sebanyak $23,07 \%$ dan pernah lupa minum obat $15,38 \%$.

Berdasarkan Tabel 3 dapat dilihat sebanyak 18 $(69,2 \%)$ penderita TB paru di Puskesmas Andalas Kota Padang memiliki pengetahuan yang baik tentang TB paru dan 30,8\% memiliki pengetahuan yang tidak baik. Penelitian yang dilakukan Fersi pada tahun 2012 di Puskesmas Mungo Kabupaten Lima Puluh Kota Provinsi Sumatera Barat mendapatkan hasil yang sama. Sebanyak 59\% responden memiliki pengetahuan yang baik tentang TB paru. ${ }^{14}$
Semua responden mengetahui bagaimana penegakkan diagnosis TB paru, lama pengobatan dan berapa kali minum obat dalam seminggu. Sebagian besar responden juga mengetahui gejala TB paru $(80,77 \%)$, minum obat harus teratur $(88,46 \%)$, dan efek samping obat $(80,77 \%)$. Pada umumnya responden tidak mengetahui penyebab TB paru adalah kuman Tuberkulosis (76,93\%). Banyak dari responden tidak mengetahui penyebab TB paru, sebagian dari responden mengira bahwa TB paru akibat virus, minuman, sering begadang, ataupun karena angin malam. Selain itu, lebih dari separuh responden tidak mengetahui kalau TB paru itu menular $(53,85 \%)$ dan yang mengetahui penularannya melalui percikan dahak hanya $42,31 \%$.

Petugas kesehatan kurang memberi informasi penyebab dan bahaya penularan TB paru. Informasi yang diberikan hanya kewajiban minum obat teratur, lama pengobatan, cara minum obat, efek sampiung obat, dan pemeriksaan dahak.

Persentase penderita yang patuh dalam minum obat TB paru sebagian besar memiliki pengetahuan yang baik $(94,4 \%)$ dibandingkan penderita yang memiliki pengetahuan yang tidak baik (12,5\%). Hasil uji statistik mendapatkan nilai $p<0,05$ ( $p=0,000)$, maka dapat disimpulkan bahwa terdapat hubungan yang bermakna antara pengetahuan pasien tentang TB paru dengan kepatuhan minum obat penderita TB paru di Puskesmas Andalas Kota Padang. Penelitian ini sesuai dengan penelitian Fersi bahwa terdapat hubungan yang bermakna antara pengetahuan seorang penderita TB paru dengan kepatuhan penderita dalam pengobatan $(p=0,045) \cdot{ }^{14}$

Menurut Notoatmodjo, perubahan perilaku itu mengikuti tahap-tahap melalui proses perubahan pengetahuan (knowledge) - sikap (attitude) - praktek (practice). ${ }^{15}$

Penderita TB paru yang patuh dalam minum obat jauh lebih tinggi pada adanya dukungan dari keluarga $(85,0 \%)$ dibandingkan dengan yang tidak mendapatkan dukungan dari keluarga $(16,7 \%)$. Hasil uji statistik diperoleh nilai $p<0,05$ ( $p=0,04)$, yang berarti terdapat hubungan yang bermakna antara dukungan keluarga dengan kepatuhan minum obat di Puskesmas Andalas Kota Padang. 
Menurut Caplan, keluarga memiliki beberapa fungsi dukungan yaitu dukungan informasional berupa informasi yang dapat meningkatkan sugesti pada individu, dukungan penilaian berupa bimbingan pada penderita, dukungan instrumental berupa perhatian pertolongan pada penderita, dan dukungan emosional berupa perhatian pada penderita. ${ }^{16}$

\section{KESIMPULAN}

Terdapat hubungan yang bermakna antara pengetahuan pasien TB paru dan dukungan keluarga dengan kepatuhan pasien dalam minum obat anti tuberkulosis di Puskesmas Andalas Kota Padang.

\section{UCAPAN TERIMA KASIH}

Terima kasih kepada Kepala Puskesmas Andalas Kota Padang dan jajarannya yang telah memberikan kesempatan dalam pengambilan data dalam penelitian ini.

\section{DAFTAR PUSTAKA}

1. Herryanto, Musadad DA, Komalig FM. Riwayat pengobatan penderita TB paru meninggal di Kabupaten Bandung. Jurnal Ekologi Kesehatan. 2004;3(1):1-6.

2. Departemen Kesehatan Republik Indonesia. Pedoman Nasional Penanggulangan Tuberkulosis. Edisi ke-2. Jakarta; 2007.

3. Burhan E. Peran ISTC dalam pencegahan MDR. Jurnal Tuberkulosis Indonesia. 2010;7:12-5.

4. Soepandi P. Diagnosis dan faktor yang mempengaruhi terjadinya TB-MDR. Jurnal Tuberkulosis Indonesia. 2010;7:16-9.

5. Departemen Kesehatan Republik Indonesia. Strategi nasional pengendalian TB di Indonesia tahun 2010-2014. Jakarta; 2011.

6. World Health Organization. Global tuberculosis control. 2012 (diunduh 3 Maret 2013). Tersedia dari: URL: HYPERLINK http://www.who.int/tb/data.
7. Dinas Kesehatan Kota Padang. Profil kesehatan tahun 2010. Padang; 2011.

8. Dinas Kesehatan Provinsi Sumatera Barat. Rekapitulasi laporan tahunan TB per kabupaten/kota tahun 2007. Padang; 2007.

9. Hutapea T. Pengaruh dukungan keluarga terhadap kepatuhan minum obat anti tuberkulosis. 2006. (diunduh 14 Januari 2013). Tersedia dari: URL: HYPERLINK http://jurnalrespirologi.org.

10. Badan Pengawas Obat dan Makanan Republik Indonesia. Kepatuhan pasien: faktor penting dalam keberhasilan terapi. Info BPOM. 2006;7(5):1-3.

11. Fitriani E. Faktor risiko yang berhubungan dengan kejadian TB paru. Unnes Journal of Public Health. 2012 (diunduh 13 Januari 2013). Tersedia dari: URL: HYPERLINK http://journal.unnes.ac.id/ sju/index.php/ujph/article/download/3034/2807.

12. Wahyuni DS. Hubungan kondisi fisik rumah dan karakteristik pasien dengan kejadian tuberkulosis paru BTA positif di puskesmas Ciputat Kota Tanggerang Selatan tahun 2012. BIMKM. 2012; 1(1):1-8.

13. Suarni H. Faktor yang berhubungan dengan kejadian penderita TB paru BTA positif di Kecamatan Pancoran Mas Kota Depok bulan Oktober tahun 2008 - April Tahun 2009 (skripsi). Jakarta: Fakultas Kesehatan Masyarakat Universitas Indonesia; 2009.

14. Fersi A. Hubungan tingkat pengetahuan penderita, peran petugas kesehatan, dan peran pengawas menelan obat (PMO) dengan kepatuhan penderita tb paru dalam pengobatan di Puskesmas Mungo Kabupaten Lima Puluh Kota Tahun 2012 (skripsi). Padang: Fakultas Kesehatan Masyarakat: Universitas Andalas; 2012.

15. Notoatmodjo S. Promosi kesehatan dan perilaku kesehatan Edisi 2012. Jakarta: Rineka Cipta; 2012.

16. Friedman M. Keperawatan keluarga : teori dan praktek. Edisi ke-3. Jakarta: Penerbit Buku Kedokteran EGC; 1998. 